\title{
ANALISIS SEMIOTIKA REPRESENTASI BUDAYA JEPANG DALAM FILM ANIME BARAKAMON
}

\author{
I.N.A. Harsana ${ }^{1}$, K.A.S. Putra ${ }^{2}$, M.Y.S. Putra ${ }^{3}$ \\ ${ }^{123}$ Jurusan Pendidikan Bahasa Jepang, Universitas Pendidikan Ganesha, Singaraja \\ e-mail: ayatmaharsana14@gmail.com, ketutagussupriadiputra12@gmail.com, yudhiareska87@gmail.com
}

\begin{abstract}
Abstrak
Penelitian ini berjudul Analisis Semiotika Representasi Budaya Jepang Dalam Film Anime Barakamon. Penelitian ini bertujuan untuk mengetahui representasi makna budaya Jepang yang terdapat pada film anime Barakamon. Barakamon (2014) merupakan anime yang bergenre comedy dan slice of life (kehidupan sehari- hari). Film Anime Barakamon menceritakan kisah seorang seniman kaligrafer kanji yang harus tinggal di sebuah desa, karena memukul seorang direktur kesenian. Selama di desa dia harus bisa beradaptasi dan membiasakan diri pada kebiasaan-kebiasaan di desa tersebut. Penelitian ini menggunakan teori Roland Barthers dengan konsep representasi budaya. Metode yang digunakan yaitu kualitatif deskriptif. Pengumpulan data menggunakan dokumentasi berupa video, buku-buku, internet, dan lain sebagainya. Teknik analisis pada penelitian ini menggunakan signifikasi dua tahap yang dikemukakan oleh Roland Barthers yaitu denotasi, konotasi, dan mitos. Denotasi merupakan tanda yang tampak pada suatu objek. Makna konotasi adalah makna yang menjelaskan arti dari suatu tanda yang tampak pada makna denotasi tersebut. Sedangkan Mitos merupakan makna yang timbul dari makna konotasi atau makna yang berkaitan dengan kebudayaan dan kepercayaan masyarakat untuk mendukung penjelasan dari makna konotasi. Hasil penelitian menunjukkan 9 scene dalam 12 episode yang mengandung budaya Jepang yaitu pada scene 15 episode 1 , scene 19 episode 3 , scene 9 episode 4, scene 2 episode 6, scene 5 episode 6, scene 2 episode 7, scene 6episode 8 , scene 9 episode 9 , scene 9 episode 10. Makna denotasi pada film ini merupakan apa yang tampak pada kisah tokoh utama dalam film ini. Makna konotasinya berupa penjelasan dari makna denotasi. Mitos pada film ini berupa kebudayaan yang yang dipengaruhi oleh kepercayaan agama.
\end{abstract}

Kata kunci: Representasi, Budaya Jepang, Film, Anime, Semiotika, Roland Barthers

\section{Pendahuluan}

Budaya berkaitan dengan bagaimana cara manusia hidup yakni mulai dari belajar berpikir, merasa, mempercayai dan mengusahakan apa yang patut menurut budayanya. Seperti bahasa, kebiasaan makan, cara komunikasi, tindakan-tindakan sosial, kegiatan ekonomi dan politik, serta teknologi berdasarkan pola-pola budaya (Mulyana dan Rahmat, 2006). Artinya budaya merupakan suatu kebiasaan yang diturunkan dari generasi terdahulu ke generasi berikutnya yang sudah melekat dan tidak bisa dipisahkan dari manusia itu sendiri.

Seiring berkembangnya zaman, budaya juga ikut berkembang. Hal ini dikarenakan adanya terpaan budaya-budaya asing yang sangat mudah masuk dan mempengaruhi pola hidup masyarakat sehari-hari. Tidak sedikit masyarakat Indonesia yang menganut budaya asing, salah satunya budaya Jepang (Sari, 2017).

Jepang merupakan sebuah negara dengan sistem pemerintahan berbentuk kerajaan konstitusional yang dipimpin oleh seorang kaisar sebagai kepala negara dan seorang perdana menteri sebagai kepala pemerintahan. Jepang merupakan bagian dari sebuah negara Asia yang letaknya terpisah dengan negara Asia lainnya, wilayahnya terdiri atas empat buah pulau besar dan ribuan pulau kecil (Kusherdyana, 2011:95).

Jepang juga memiliki dan mengembangkan budaya pop. hal ini dipengaruhi oleh fenomena globalisasi. Budaya pop Jepang adalah salah satu budaya yang paling populer di dunia dalam beberapa tahun terakhir. Hal tersebut dikarenakan, popularitas produk kebudayaan Jepang seperti anime dan manga sangatlah besar, 
terutama sudah memiliki jangkauan audiens yang sangat luas serta mencangkup di berbagai kalangan. Pada tahun 2014, kementrian luar negeri Jepang mengumumkan "Pop Culture Diplomacy" sebagai salah satu agenda politik luar negeri mereka. (Hirzi, 2017:2).

Pada tahun 1990-an dimana Jepang mulai memperkenalkan budaya- budaya ke seluruh dunia melalui TV show Jepang. Film anime atau animasi yang diproduksi oleh Jepang itu sangat populer di Indonesia. Karena anime memiliki salah satu peran yang penting sebagai media yang mempererat hubungan bilateral kedua negara tersebut, walau pada awal masuknya anime di Indonesia belum menunjukkan pengaruhnya. Namun seiring berjalannya waktu anime mampu menjadi salah satu bentuk kerjasama Jepang dengan Indonesia. Dengan demikian anime mampu merubah pola pikir masyarakat Indonesia yang dulunya menganggap Jepang sebagai negara penjajah, namun tidak demikian halnya saat anime mulai diterima, dan akhirnya Jepang pun dianggap bersahabat karena memegang teguh budayanya, kemudian hal ini mendapat respon positif dari rezim pemerintah orde baru, hingga sampai saat ini budayanya telah diterima luas oleh masyarakat Indonesia (Safariani, 2017:737).

Dilain sisi, film merupakan salah satu media komunikasi massa yang memiliki kapasitas untuk memuat pesan yang sama secara serempak dan mempunyai sasaran yang beragam dari agama, etnis, status, umur, dan tempat tinggal dapat memainkan peranan sebagai saluran penarik untuk pesan-pesan tertentu dari dan untuk manusia. Dengan melihat film kita dapat memperoleh informasi dan gambar tentang realitas tertentu, atau realitas yang sudah diseleksi (Muhtadi dan Handayani, 2000:95).

Dari uraian di atas, peneliti tertarik untuk meneliti budaya Jepang terutama dalam film anime. Adapun film anime yang akan diteliti adalah Barakamon. Peneliti memilih anime Barakamon dikarenakan pada anime Barakamon memberikan gambaran kepada penonton bagaimana kehidupan di desa dan unsur-unsur budaya Jepang yang lebih tradisional dibandingkan dengan kebanyakan anime lain yang terutama pada beberapa anime sekarang yang lebih mengarah pada jalan cerita yang fantasi, kekerasan, dan percintaan.

Anime Barakamon memiliki total 12 episode yang berdurasi 23 menit per episodenya. Anime ini hadir dengan genre comedy, slice of life (kehidupan seharihari). Barakamon ditujukan untuk remaja dan tayang pada musim panas mulai tanggal 06 Juli 2014 sampai 28 September 2014 dan memiliki skor 8.3 (myanimelist.net, 2014). Melalui pendekatan semiotika peneliti akan mencari nilainilai dan makna dari setiap tanda pada anime tersebut. Berdasarkan fenomena dan sinopsis di atas, maka peneliti mengambil judul "Analisis Semiotika Representasi Budaya Jepang Dalam Film Anime Barakamon”. Rumusan masalah dalam penelitian ini adalah bagaimana representasi budaya Jepang dalam anime Barakamon.

\section{Teori Semiotika Roland Barthers}

Dalam teorinya Barthers melontarkan konsep tentang denotasi dan konotasi. Lewat konsep ini Barthers menjelaskan bahwa signifikasi tahap pertama merupakan hubungan antara signifier (ekspresi) dan signified (konten) di dalam sebuah tanda. Hal inilah yang Barthers sebut sebagai denotasi yaitu makna sebenarnya dari tanda (sign).

Konotasi adalah signifikasi tahap kedua yang menggambarkan interaksi yang terjadi ketika tanda (denotasi) bertemu dengan perasaan atau emosi serta nilai-nilai dari kebudayaannya. Konotasi mempunyai makna yang subjektif, dengan kata lain denotasi adalah suatu gambaran pada tandaterhadap suatu objek, sedangkan konotasi adalah makna dari suatu tanda tersebut (Wibowo, 2013:21-22).

Pada signifikasi tahap kedua yang berhubungan dengan isi, tanda bekerja melalui mitos (myth). Mitos adalah bagaimana kebudayaan menjelaskan atau 
memahami beberapa aspek tentang realitas atau gejala alam. Mitos bisa dikatakan sebagai suatu wahana dimana suatu ideologi berwujud. Mitos dapat berupa mitologi yang menjadi peranan penting dalam kesatuan-kesatuan budaya (Wibowo, 2013:22).

Dalam arti lain, Barthers mengartikan mitos sebagai "cara berpikir kebudayaan tentang sesuatu, sebuah cara konseptualisasi atau memahami sesuatu hal". Barthers juga menyebut mitos sebagai rangkaian konsep yang berkaitan (Sobur, 2013:224).

\section{Representasi}

Representasi merupakan kegunaan dari tanda. Marcel Danesi (2010, dalam Wibowo, 2013), representasi adalah proses merekam ide, pengetahuan, atau pesan dalam beberapa cara fisik disebut representasi. Disisi lain pengertian representasi adalah suatu tindakan yang menghadirkan seseuatu lewat sesuatu yang lain di luar dirinya, dan biasa berupa tanda atau simbol (Yasraf, 2003:21). Konsep "representasi" dalam studi media massa seperti film, dapat dilihat dari beberapa aspek yang tergantung pada sifat kajiannya.

\section{Budaya Jepang}

Budaya Jepang adalah bagaimana cara masyarakat Jepang hidup. mulai dari bahasa, berbicara, kepercayaan, kebiasaan makan, cara berkomunikasi, melakukan tindakan-tindakan sosial, dan lain-lain sebagainya yang didasari menurut budayanya.

\section{Film Sebagai Media Komunikasi}

Film sebagai salah satu media komunikasi massa yang memiliki kapasitas untuk memuat pesan yang sama secara serempak dan mempunyai sasaran yang beragam dari agama, etnis status, umur dan tempat tinggal yang dapat memainkan peranan sebagai saluran penarik untuk pesan-pesan tertentu dari dan untuk manusia. Degan melihat film, kita dapat memperoleh informasi dan gambar tentang realitas tertentu yang sudah diseleksi (Muhtadi dan Handayani, 2000: 95).

Anime merupakan animasi khas Jepang yang digambarkan dengan tangan maupun menggunakan teknologi komputer. Anime berasal dari kata animejyon, biasanya dicirikan melalui gambar-gambar berwarna-warni yang menampilkan tokoh dalam berbagai lokasi dan cerita yang ditujukan pada beragam jenis penonton. Anime dipengaruhi oleh gaya gambar manga yaitu komik khas Jepang. Animasi dengan anime bisa dikatakan memiliki kemiripan yakni, animasi lebih kepada semua jenis film yang diproduksi dari beberapa negara, sedangkan anime lebih menuju pada animasi yang diproduksi oleh Jepang (Riyana, 2017:6).

\section{Metode}

Pendekatan penelitian yang digunakan dalam penelitian ini adalah pendekatan kualitatif. Unit analisis data dalam penelitian ini adalah scene- scene dalam film anime Barakamon yang mempresentasikan budaya Jepang, baik penampilan karakter, suara, kostum pada karakter, serta pesan-pesan verbal dan non verbal dalam scene-scene tersebut yang nantinya akan diteliti menggunakan teori semiotika Roland Barthers. Teknik analisis data dengan melakukan pengamatan terhadap objek penelitian dan tahap analisis.

\section{Hasil dan Pembahasan}

Hasil penelitian menunjukkan 9 scene dalam 12 episode yang mengandung budaya Jepang yaitu pada scene 15 (cara meminta maaf di Jepang), scene 19 episdoe 3 (melempar kue mochi sebagai rasa syukur), scene 9 episode 4 (representasi kanji), scene 2 episode 6 (tatakrama saat makan di Jepang), scene 5 episode 6 (cara memanggil nama orang di Jepang), scene 2 episode 7 (Dewa Ebisu 
sebagai simbol keberuntungan), scene 6 episode 8 (perayaan festival obon), scene 9 episode 9 (kebiasaan berendam bagi masyarakat Jepang), scene 9 episode 10 (perayaan matsuri di Jepang).

Hasil temuan scene-scene dalam film ini, merupakan bentuk budaya Jepang yang divisualisasikan beberapa menyangkut kebiasaan dan nilai agama. Secara tidak langsung, gambaran yang ingin disampaikan berkenaan dengan gambaran kehidupan masyarakat Jepang. Melalui mitos budaya yang ditampilkan dalam film, sebagai symbol budaya yang kuat.

Representasi budaya Jepang yang digambarkan melalui film anime Barakamon berupa tanda yang bersifat verbal dan non verbal, yang dijadikanpeneliti sebagai tanda dalam memaknai sebuah tanda. Melalui film ini, diharapkan bukan hanya sekedar untuk menghibur khalayak yang menontonnya, terutama karena termasuk jenis film animasi. Akan tetapi juga mampu memberikan informasi yang akurat tentang kebudayaan Jepang, sehingga bias dijadikan sebuah pembelajaran lebih bagi khalayak yang menonton dan ingin mempelajari budaya Jepang.

\section{Simpulan dan Saran}

Berdasarkan dari hasil penelitian dan pembahasan yang dilakukan oleh peneliti dalam menganalisis data berupa data adegan-adegan (scene- scene) dalam film anime Barakamon dengan menggunakan teori Roland BArthers, dapat ditarik kesimpulan sebagai berikut :

a. Makna Denotasi

Makna denotasi pada film anime Barakamon terdapat pada symbol atau yang dipresentasikan secara verbal dan non verbal dari setiap cene pada jalan cerita tokoh utama mengenai budaya-budaya Jepang yang terdapat di film anime tersebut.

b. Makna Konotasi

Makna konotasi terdapat pada perilaku tokoh dan komunikasi verbal maupun non verbal antar tokoh mengenai budaya yang biasanya dilakukan oleh masyarakat Jepang terutama pada budaya di musim panas.

c. Makna Mitos

Mitos dalam film anime ini dapat dilihat dari kebudayaan Jepang yang dipengaruhi oleh agama Shinto. Agama Shinto merupakan ajaran yang menyembah para dewa-dewa dana segala kekuatan yang ada di alam semesta. Salah satu kebudayaan Jepang dari ajaran Shinto yang ditampilkan oleh film ini adalah Obon Matsuri (Festival pulangnya roh para leluhur) yang dimana pada festival ini diadakan pada musim pada tanggal 15 Agustus selama 5 hari. Tradisi ini dilakukan untuk menghormati para leluhur pulang ke rumah ataua ke dunia. Selain itu, pelaksanaan tradisi ini juga berbeda-beda pada setiah daerah.

Berdasarkan hasil penelitian yang telah dilakukan, maka peneliti dapat memberikan beberapa masukan/saran sebagai berikut :

a. Pada penelitian ini ada beberapa kelemahan yakni peneliti hanya menganalisis budaya Jepang berdasarkan apa yang ditampilkan pada film saja. Maka, untuk memyempurnakan penelitian ini diharapkan ada penelitian lebih lanjut untuk membahas lebih rinci mengenai budaya Jepang.

b. Film anime Barakamon sangat bagus dan tidak mengandung pornografi, sehingga layak ditonton oleh masyarakat umum. Anime ini direkomendasikan bagi masyarakat yang ingin belajar atau ingin mengetahui budaya Jepang, terutama budaya Jepang yang ada di musim panas. Kemudian film anime ini juga memberikan pesan bahwa ketika ingin berhasil jangan pantang menyerah dan terus berusaha, 
serta hargai segala masukan dan kritikan dari orang lain terhadap diri sendiri, untuk memperbaiki diri sendiri.

\section{Daftar Pustaka}

Berita Satu. (2014, 2 Desember). Indonesia Negara Kedua dengan Peminat Belajar Bahasa Jepang Tertinggi. Diakses dari http://www.beritasatu.com/pendidikan/229871-indonesia-negara- kedua-denganpeminat-belajar-bahasa-jepang-tertinggi.html pada tanggal 19 Februari 2018.

Hirzi, Hadyan, Muhammad. (2017). Globalisasi Budaya Pop Jepang Melalui Industri Kreatif Jepang Di Indonesia. Skirpsi. Fakultas Ilmu Sosial Dan Politik Universitas Gadjah Mada Yogyakarta.

Kusherdyana. (2011). Pemahaman Lintas Budaya dalam Konteks Pariwisata dan Hospitalisasi. Bandung: Penerbit Alfabeta.

Muhtadi, Asep S. dan Handayani, Sri. (2000). Dakwah Kontemporer: Pola Alternatif Dakwah Melalui TV. Bandung: Pusdai Press

Myanimelist.net. (2014). Barakamon. Diakses pada tanggal 10 Juli 2018 dari https://myanimelist.net/anime/22789/Barakamon.

Riayana, Elma. (2017). Analisis Semiotika Film Kimi No Nawa (Your Name). Skripsi. Fakultas IImu Sosial Dan IImu Politik Universitas Pasundan Bandung.

Sari, Permata, Indah. (2017). Pengaruh Terpaan Anime Di Media Massa Terhadap Gaya Hidup Perilaku Anggota Islamic Otaku Community (IOC) Episode UIN Jakarta. Skripsi. Fakultas IImu Dakwah Dan IImu Komunikasi Universitas Islam Negeri Syarif Hidayatullah Jakarta.

Safriani, Putri. (2017). Penyebaran Pop Culture Jepang Oleh Anime Festival Asia (AFA) Di Indonesia Tahun 2012-2016. Volume 5, No. 3: 729-744. FISIP Universitas Mulawarman

Sobur, Alex. (2013). Semiotika Komunikasi. Bandung: PT. Remaja Rosdakarya.

Wibowo, Wahyu, Seto, Indiwan. (2013). Semiotika Komunikasi-Aplikasi Praktis Bagi Penelitian Dan Skripsi Komunikasi. Jakarta: Penerbit Mitra Wacana Media.

Yasraf, Amir P. (2003). Hipersemiotika. Yogyakarta: Jala Sutra. 